\title{
Influence of Emotional Intelligence on Organizational Performance Among Insurance Companies in Kenya
}

\author{
Mwangi Grace Wangari ${ }^{1}{ }^{\dagger}$, Gichuhi D. M. ${ }^{2}$, Macharia S. M. ${ }^{3}$ \\ ${ }^{1}$ Department of Human Resource Development, School of Business, Karatina University, P.O. BOX 1957—10101, Karatina \\ ${ }^{2}$ Department of Human Resource Development, School of Business, Karatina University \\ ${ }^{3}$ Business and Economics Department, School of Business, Karatina University
}

\begin{tabular}{l}
\hline ARTICLE INFO \\
\hline Article History \\
Received 28 May 2019; \\
Accepted 22 October 2019 \\
\hline JEL Classifications \\
L60, M12, M16
\end{tabular}

ABSTRACT

\section{Purpose:}

The purpose of this study was to establish the influence of emotional intelligence on organizational performance among insurance companies in Kenya.

JEL Classifications

Design/methodology/approach:

Positivism research philosophy was adopted for the study. Descriptive and explanatory cross-sectional research designs were used. The target population consisted of all the 55 registered insurance companies in Kenya as at 28th February 2017 and a sample size of 208 participants drawn from lower, middle and top level. Primary data was collected using collected using semi-structured questionnaires containing both open and closed-ended questions while secondary data was obtained using a secondary data collection sheet. Data analysis was conducted using descriptive statistics and inferential analysis.

Findings:

There is a weak positive correlation between self-awareness and organization performance. Self-management, social awareness, and organization performance were moderately correlated while interpersonal relationship management was strongly correlated with organization performance. Emotional intelligence has a significant influence on organizational performance among insurance companies in Kenya. Specifically, selfawareness, self-management, social awareness, and interpersonal relationship management have a significant impact on organizational performance among insurance companies in Kenya.

Research limitations/implications:

Keywords:

Emotional Intelligence, Organizational Performance, Insurance companies
Study was limited in scope since it focused on the Kenyan insurance firms and thus the findings might not be generalized to other sectors such as banking and agricultural sectors. The management of insurance companies should ensure that they cultivate, create and maintain good rapport with stakeholders, seek to understand each stakeholder requirements, observe healthy competition with competitors, encourage amicable conflict resolution where grievances arise and enhance effective communication within and outside the organization. Insurance companies should ensure that there are programs that are specially designed to offer training and enhancement of self-awareness to help the management staff and employees to be emotionally stable and make optimal decisions.

Originality/value:

The results of this research will add knowledge in the available literature on emotional intelligence and how it impacts on the performance of organizations by showing that emotional intelligence plays a significant role in personal career development and motivating people to act and control their actions and emotions. 


\section{Introduction}

In the last decade, the Kenyan insurance industry has faced hard economic times with a penetration rate of under $3 \%$. This has resulted in a number of insurance companies bowing to pressure and exiting the market (IRA, 2016). Mohanty and Kar (2012) indicated that employee performance is a function of motivation and ability. Hence, competency mapping, if well understood and adopted forms an important resource management strategy which allows the firm to build their employees competencies, to employ the best suited job seekers for a role, assign duties to the most suitable candidate and come up with proper succession plans and talent management strategies (Almajali, Alamro and Al-Soub, 2012; Wambua, 2016). As proposed in the competency theory, which is linked to the resourcebased view theory, firms are viewed as open systems that are guided by a strategic logic derived from managerial cognitions and governed by management processes.

Teece (2010) described a firm's competence, as special capabilities that might be in terms of technological abilities, unique assets or an organisations culture or way of doing things that provide an organisation with superior performance. These competences offer the firm in possession a competitive edge allowing them superior performance. The theory relates to the current study because it allows the linkage between the construct of emotional intelligence to the performance of companies in the insurance sector in Kenya.

Consequently, emotional intelligence as explained by Brackett, Rivers and Salovey (2011) is the ability to identify, manage and use emotions to guide decision-making. It may also be viewed as the ability to understand emotions. By assimilating emotions in ones thoughts, one is able to understand and control their emotions. The emotions are made up of feelings such as of pleasure and pain and often operate on interpersonal and intrapersonal states. Watson (2000) observed that emotional intelligence plays a significant role in personal career development and motivating people to act as well as control their actions. Based on this argument, it is imperative that every manager understands the emotional intelligence of their employees since this contributes to how one handles the needs of individuals, how he motivates and make them feel comfortable which increases organizational performance.

\section{Literature Review}

This study was anchored on competency theory which is credited to Harter's $(1978,1981)$ who points out that organisations require to have competency as a trait that emphasises on the need of the firm to have capabilities and resources particularly knowledge to maximize performance (Qiao, Zhang \& Cheng, 2016). Birgit (2010) study that was based in Namibia looked at the association between emotional intelligence and leadership among Namibian based middle managers with the aim of looking into traits of emotional intelligence and if these had any impact on the middle managers leadership styles. According to the results most of the middle managers in Namibia used the transactional style of leadership, the study further showed no significant association between transactional leadership and emotional intelligence. Moreover, Acha (2013) did a research looking at the relationship between a leaders emotional intelligence and employee motivation to job performance and established that emotional intelligence affects performance.

In a study conducted to establish the relationship between emotional intelligence and job performance, Mwathi (2013) found that there was a moderate and positive relationship between emotional intelligence and job performance. In addition, Nzomo (2012) studied the relationship between principals' emotional intelligence and students' learning achievements. Adopting a correlation research design, he indicated that there existed a significant association between emotional intelligence of principals and students' academic achievements in national schools and in co-curricular activities. On the other hand, Omondi (2016) sought to establish the influence of manager's emotional intelligence on employee job satisfaction at the Kenya Post Office Savings Bank and found out that there is a significant and strong relationship between manager's emotional intelligence and employee job satisfaction.

Literature indicates that there are studies done in the past touching on emotional intelligence. Other variables that relate to emotional intelligence including leadership style (Birgit, 2010), employee motivation (Acha et al., 2013), job performance (Mwathi, 2013), academic performance (Nzomo, 2012) and job satisfaction (Omondi, 2016) are the ones targeted in these studies.

Additionally, the study finds that a contingent of research has been done in the education sector as well as in the banking sector hence there is limited literature on the relationship between emotional intelligence and firm's performance. The study sought to fill the gap by determining the relationship between emotional intelligence and organizational performance in the insurance industry in Kenya. 


\section{Methodology, Results and Discussions}

The research philosophy adopted for the study was positivism. The positivistic philosophical foundation focuses on facts, measuring, validity, neutrality, and objectivity of the findings (Saunders, 2011). According to the positivism view, knowledge should be provided through facts and not abstracts. The quantitative nature of data in the current research is from the positivist philosophy which points out that objective realities exist and they can be shown in numeral forms (Bryman \& Bell, 2015). The study adopted the descriptive and explanatory research designs. The target population for the study was comprised of the management staff of all the 55 registered insurance companies in Kenya and a sample size of 208 participants drawn from lower, middle and top level management using stratified sampling and simple random sampling techniques.

The study used both primary and secondary data. Primary data was collected using questionnaires and on the other hand, secondary data was collected using a secondary data collection sheet. The questionnaire was structured to contain two sections; the first section was the demographic section that entailed questions regarding the respondents and the second section contained questions (closed and open ended) regarding the study variables (Emotional Intelligence and Organizational Performance). Emotional Intelligence was operationalized into: Self-Awareness, SelfManagement, Social Awareness and Interpersonal Relations Management as opined by Vito-Thomas, Allyn, Wagner, Hodges and Streitmatter (2018). On the other hand Organizational Performance was measured in terms of Sales Volume and Profitability (Corvellec 2018).

The respondents were required to respond to the research items on the extent to which they agree with the statements on the aspects of study variables in a 5-point Likert scale where 5- was very large extent and 1 represented no extent. Moreover, Pilot testing was done to ensure that the research tool was valid and reliable and also to improve its face validity (Smith, 2015). Data analysis was conducted using descriptive statistics and inferential statistics as well as SPSS software. Descriptive statistics mainly; frequencies, the mean, and standard deviation were computed for each of the study variables in order to allow the researcher come up meaningful scores that used few indices (Taylor, Bogdan \& DeVault, 2015). Inferential data analysis was conducted using Pearson correlation coefficient and regression analysis (multiple regression analysis). The coefficient of determination $\left(\mathrm{R}^{2}\right)$ was used to determine if the model was significant and the extent to which each of the independent variables explained the changes in the dependent variable.

The study used descriptive and inferential statistics to make conclusions on the relationship existing between the study variables. Emotional intelligence was the independent variable in the study. The variable was adopted due to its contribution to employee stability for effective decision making. Brackett, Rivers and Salovey (20 11) observed that it is important for the management staff to understand emotion, assimilate it and reason with it in their minds. In this study, emotional intelligence was measured through self-awareness, self-management, social awareness and interpersonal relations. The descriptive results were as presented in Table 1.

Table 1: Descriptive Statistics for Emotional Intelligence

N Min Max Mean $\begin{gathered}\text { Std. } \\ \text { Deviation }\end{gathered}$

\section{Interpersonal relations management}

This company strongly emphasise on management of relationships within the organisation

We pride in having the best interpersonal relations management in our organization

A key pillar of our success is good employer - employee relations

A key pillar of our success is good employee - employee relations
153

153

153

153

1

1

1.98

1.138

Average

3.68

0.982

\section{Self-management}




$\begin{aligned} & \text { Our company endeavours to establish the strengths and } \\ & \text { weaknesses our staff. }\end{aligned}$
$\begin{aligned} & \text { We train our staff on how to control themselves through tasks } \\ & \text { Average }\end{aligned}$

\section{Social awareness}

We encourage our staff to work in teams

153

1

1

5

2.37

1.056

Our company always seek to establish the staff level of social

153

5

2.03

1.100 awareness

Average

2.20

1.078

\begin{tabular}{|c|c|c|c|c|c|}
\hline \multicolumn{6}{|l|}{ Self-awareness } \\
\hline $\begin{array}{l}\text { This company regularly undertake to assess the staff level of } \\
\text { self-awareness }\end{array}$ & 153 & 1 & 5 & 2.07 & 1.151 \\
\hline We train our staff on self-awareness on a regular basis & 153 & 1 & 5 & 1.91 & 1.132 \\
\hline Average & & & & 1.99 & 1.142 \\
\hline Aggregate Score & & & & 2.787 & 1.0579 \\
\hline
\end{tabular}

Source: Survey Data (2018)

The results in Table 1 indicated that emotional intelligence was emphasised to a moderate extent as shown by aggregate mean score of 2.787 . However, there was a high degree of variance in the observations made by the respondents as shown by the high aggregate standard deviation of 1.0579. These results may suggest that the respondents believed that emotional intelligence has a moderate influence on performance of insurance companies in Kenya. This conclusion was similar to that of Mwathi (2013) who reported a moderate favourable association between emotional intelligence and job performance. Similarly, Acha (2013) concluded that there exists a positive relationship between emotional intelligence and performance. At the same time, Omondi (2016) concluded that there exists a significant and strong relationship between manager's emotional intelligence and employee job satisfaction.

The results further showed that interpersonal relations management was the most adopted element of emotional intelligence as shown by an average mean score of 3.68. There was a general agreement on the emphasis of the construct among the respondents with a low standard deviation of 0.982 . The second most, emphasised element of emotional intelligence was self-management with a mean score of 3.24 followed by social awareness and selfawareness with a mean score of 2.20 and 1.99 respectively.

In particular, the results suggested that most insurance companies in Kenya endeavour to establish the strengths and weaknesses their staff to a great extent, strongly emphasise on management of relationships to a great extent and pride in having the best interpersonal relations management to a great extent as shown by a mean score of $4.01,3.98$ and 3.92 respectively and a standard deviation of $0.827,0.892$ and 0.892 respectively. The study also found that employer - employee relations formed a key pillar of success in the insurance companies in Kenya to a moderate extent as shown by a mean score and a standard deviation of 3.14 and 1.161 respectively. The results also indicated that insurance companies in Kenya trained their staff on how to control themselves but to a low extent, encourage teamwork among staff to a low extent, regularly assess the staff level of self-awareness to a low extent, always seek to establish the staff level of social awareness to a low extent, encourage good employee - employee relations and trained their staff on self-awareness on a regular basis to a low extent as shown by a mean score of 2.46, 2.37, 2.07, 2.03, 1.98 and 1.91 and a standard deviation of $1.230,1.056,1.151,1.100,1.138$ and 1.132 respectively.

The study also descriptively analysed the performance of insurance companies in Kenya. To facilitate analysis, the data collected using secondary data collection sheet was converted into a 5-point Likert scale. Regarding sales, 1 represented values less than one billion, 2 represented values greater than one billion but less than two billion, 3 represented values greater than two billion but less than three billion, 4 represented values greater than three billion 
but less than four billion while 5 represented values greater than four billion. On profitability ratios, 1 represented a ratio less than $0 \%, 2$ represented a ratio greater than $0 \%$ but less than $10 \%, 3$ represented a ratio greater than $10 \%$ but less than $20 \%$, 4 represented a ratio greater than $20 \%$ but less than $30 \%$ while 5 represented a ratio greater than $30 \%$. Descriptive results for performance were as presented in Table 2.

Table 2: Descriptive Statistics for Performance

\begin{tabular}{lccccc}
\hline & N & Minimum & Maximum & Mean & Std. Deviation \\
\hline Sales Volume & 153 & 1.10 & 5.00 & 3.3497 & .89928 \\
ROSE & 153 & 1.00 & 5.00 & 3.3399 & .93396 \\
ROTA & 153 & 1.00 & 5.00 & 3.3098 & .91499 \\
Aggregate Score & $\mathbf{1 5 3}$ & & & $\mathbf{3 . 3 3 3}$ & $\mathbf{0 . 9 1 6}$ \\
\hline
\end{tabular}

Source: Survey Data (2018)

The results in Table 2 above showed that most insurance companies had sales volumes greater than $10 \%$ but less than $20 \%$ as shown by a mean score of 3.3497 , Return on Shareholders' Equity (ROSE) ranked second with a mean score of 3.3399 meaning that in most insurance companies the ROSE were greater than $10 \%$ but less than $20 \%$ while many insurance companies had their Return on Total Assets (ROTA) greater than $10 \%$ but less than $20 \%$. The aggregate mean score for performance was 3.333 which means that the insurance industry in Kenya posted moderate results during the period. However, the results also showed that there was high variability in these results as shown by the standard deviations. ROSE had the highest dispersion with a standard deviation of 0.93396 followed by ROTA with a standard deviation of 0.91499 and finally sales volume with a standard deviation of 0.89928 . These results implied that while there were some insurance companies that were performing well, there were some others that produced very poor results.

The results posted on this variable agreed with the observations of IRA, 2016 that showed that the insurance industry in Kenya had faced hard economic times and showed average performance with a number of insurance companies exiting the market. Similarly, Ngugi (2007), Ndura (2010), Alipour (2012), Ntinyari (2014) and Mwangi and Murigu (2015) indicated that changing interest rates, mispricing of insurance policies, natural catastrophes, changes in legal framework, false claims by fraudulent customers, inadequate human resource capacities and competences had led to poor performance and mortality of most insurance companies in Kenya.

\section{Reliability of the Research Instruments}

The study also tested the reliability of the questionnaire aimed at establishing the extent to which the questionnaire produces the same results under similar circumstances but on different scenarios as noted by Bell (2010). In this study, the research tool reliability was assessed through internal consistency using Cronbach's alpha $(\alpha)$. A construct composite reliability co-efficient (Cronbach alpha) of 0.6 or above is considered adequate (Bryman \& Bell, 2015). Based on this argument, a coefficient of 0.6 or above for all the constructs was accepted. The reliability test findings are as indicated in Table 3.

Table 3 : Summary of Reliability Statistics

\begin{tabular}{lcc}
\hline Variable & Cronbach's Alpha coefficient & Conclusion \\
Self-Awareness & & Reliable \\
Self-Management & 0.887 & \\
Social Awareness & 0.773 & \\
Interpersonal Relationship Management & 0.887 & Reliable \\
Performance & 0.925 & Reliable \\
Overall Cronbach's Alpha & 0.958 & 0.890 \\
\hline
\end{tabular}

Source: Survey Data (2018)

The summary of reliability statistics shown in Table 3 above, indicates that overall, the Cronbach's Alpha coefficient for all the variables was 0.890 . Self-awareness had a coefficient of 0.887 , the coefficient for self-management was 0.773 , social awareness 0.887 , interpersonal relationship management 0.925 while performance had a coefficient of 0.958 . The study relied on the recommendations of Bryman and Bell (2015) who indicated that a coefficient of 0.6 or above is 
considered adequate. Based on these results the study found that all the constructs had internal consistency since all the Cronbach's Alpha coefficients were greater than 0.6.

The study sought to determine the effect of emotional intelligence as measured through self-awareness, selfmanagement, social awareness, and interpersonal relationship management on performance of insurance companies in Kenya. The results of the study were interpreted using the $\mathrm{R}^{2}$, F-statistic, t-test statistics and the P-values. Multiple linear regression analysis was conducted in which organisation performance was regressed on emotional intelligence and the model summary results were as shown in Table 4.

Table 4: Model Summary

\begin{tabular}{lcccc}
\hline Model & $\mathbf{R}$ & R Square & Adjusted R Square & Std. Error of the Estimate \\
\hline 1 & $.446^{\mathrm{a}}$ & .199 & .177 & .78622 \\
\hline
\end{tabular}

a. Predictors: (Constant), Interpersonal Relationship Management, Social Awareness, Self-Awareness, Self-

Management

Source: Survey Data $(2019$

The results shown in Table 4 showed that the correlation coefficient $(\mathrm{R})$ was 0.446 indicating that there was a medium favourable correlation between organisation performance and emotional intelligence. At the same time the results showed that the coefficient of determination, which measures the percentage of the changes in the dependent variable that can be associated by variations in the independent variable, as shown by the adjusted $\mathrm{R}$ Square $\left(\mathrm{R}^{2}\right)$ was 0.177 meaning that the model predicted $17.7 \%$ of all the variations in organizational performance among the selected Kenyan insurance firms. These results implies that $82.3 \%$ of the variations in the performance of Kenyan based insurance firms were attributed to other factors other than self-awareness, self-management, social awareness, and interpersonal relationship management.

To establish the Fitness of the model in predicting organisation performance, the study conducted an Analysis of Variance (ANOVA) and the findings are as indicated in Table 5.

Table 5: ANOVA ${ }^{\mathrm{a}}$ Results

\begin{tabular}{llccccc}
\hline Model & & Sum of Squares & df & Mean Square & F & Sig. \\
\hline 1 & Regression & 23.2 & 4 & 5.8 & 9.197 & $.000^{\mathrm{b}}$ \\
& Residual & 93.399 & 148 & .631 & & \\
& Total & 116.539 & 152 & & & \\
\hline
\end{tabular}

a. Dependent Variable: Organisation Performance

b. Predictors: (Constant), Interpersonal Relationship Management, Social Awareness, Self-Awareness, Self-

Management

Source: Survey Data $(2019$

The ANOVA results showed that the F-statistic for the model was 9.197, which was found to be greater than the Fcritical value (2.433). Therefore on the basis of the F-statistic, the study concluded that the model was a good fit and could be used to predict the performance of the selected Kenyan insurance firms. Further, the results showed that the significance level for the F-test statistic was 0.000 which was less than the significance level of 0.05 . The conclusion made was that the F-test statistic was significant and therefore the model was fit in predicting performance of Kenyan based insurance firms.

To determine the significance of the model coefficient and the constant, the study conducted a t-test for the study coefficients and the findings are as indicated in Table 6.

Table 6: Table of Coefficients ${ }^{a}$

\begin{tabular}{|c|c|c|c|c|c|}
\hline \multirow[t]{2}{*}{ Model } & \multicolumn{2}{|c|}{ Unstandardized Coefficients } & \multirow{2}{*}{$\begin{array}{c}\text { Standardized } \\
\text { Coefficients } \\
\text { Beta }\end{array}$} & \multirow[t]{2}{*}{$\mathbf{t}$} & \multirow[t]{2}{*}{ Sig. } \\
\hline & B & Std. Error & & & \\
\hline (Constant) & 3.714 & .535 & & 6.944 & .000 \\
\hline Self-Awareness & 0.108 & 0.012 & 0.108 & 9.000 & 0.000 \\
\hline Self-Management & 0.132 & 0.046 & 0.122 & 2.870 & 0.005 \\
\hline Social Awareness & 0.122 & 0.034 & 0.194 & 3.588 & 0.000 \\
\hline $\begin{array}{l}\text { Interpersonal Relationship } \\
\text { Management }\end{array}$ & 0.179 & 0.021 & 0.173 & 8.524 & 0.000 \\
\hline
\end{tabular}

a. Dependent Variable: Organisation Performance

Source: Survey Data $(2019$

DOI: 10.25103/ijbesar.122.04 
As observed in in Table 6, the constant had an unstandardized coefficient of 3.714. This indicates that holding all factors constant at zero (0), performance of the selected insurance companies in Kenya would be equal to 3.714. The results further showed that self-awareness had an unstandardized coefficient of 0.108 implying that if all other factors were held constant a rise in self-awareness by a unit would result in a 0.108 rise in the performance of Kenyan insurance firms. Similarly, self-management had an unstandardized coefficient of 0.132 indicating that holding all other factors constant, a unit increase in self-management would result in a 0.132 increase in performance of insurance companies in Kenya.

Social awareness had a coefficient of 0.122 suggesting that holding all other factors constant, a unit increase in social awareness would result in a 0.122 increase in performance of insurance companies in Kenya. Finally, interpersonal relationship management had a coefficient of 0.179 indicating that if all other factors were held constant and interpersonal relationship management increased by one unit, performance of insurance companies in Kenya would increase by 0.179. Based on the magnitude, interpersonal relationship management had the highest effect followed by self-management, and social awareness while self-awareness had the least effect.

It was also noted that the constant had a t-statistic of 6.944 which was greater than the t-critical value (t-critical at $152 \mathrm{df}$ and 0.05 significance level= 1.655). Thus based on the t-statistic results, the conclusion made was that the constant was significant. Moreover, the results showed that self-awareness had a t-statistic of 9.000, for selfmanagement was 2.870 , for social awareness was 3.588 while for interpersonal relationship management was 8.524 . It was established that the t-statistics for all the study variables were greater than the t-critical value (at $152 \mathrm{df}$ and 0.05 significance level= 1.655). Further, the results in Table 6 showed that the P-value for the constant and all study variables were less than the significant level of 0.05 . Based on these results the study concluded that self-awareness, self-management, social awareness, and interpersonal relationship management have a significant impact on organizational performance among insurance companies in Kenya.

The model was thus summarised as follows:

Organisation Performance $=3.714+0.108$ Self-Awareness +0.132 Self-Management +0.122 Social Awareness + 0.179 Interpersonal Relationship Management $+\varepsilon$

The conclusion reached on this variable tallied with the observations made by Watson (2000) who stated that emotional intelligence had a significant effect on personal career development and motivating people to act as well as control their actions. Additionally, the results posted on this hypothesis were in agreement with the results shown by Acha (2013) who showed that the emotional intelligence level of a leader affected the motivation of the workers to excel. Similarly, Mwathi (2013) studying the association between emotional intelligence and service providers job performance determined that a moderate favourable association did exist between the study variables as was found in the current study.

\section{Correlation Analysis}

The aim of this part of the study was to deduce if the variables in the study were correlated with each other. The decision on the strength of correlation coefficient was based on Dancey and Reidy (2004) who stated that if the correlation coefficient is equal to 1 , then there is perfect correlation, if the correlation coefficient lies between 0.7-0.9, there is a strong correlation, if the correlation coefficient lies between 0.4-0.6 there is moderate extent correlation, if the correlation coefficient lies between $0.1-0.3$, there is weak correlation and if the correlation coefficient is 0 , then there is no correlation. The results of the correlation analysis were as shown in Table 7 .

Table 7: Correlations coefficients

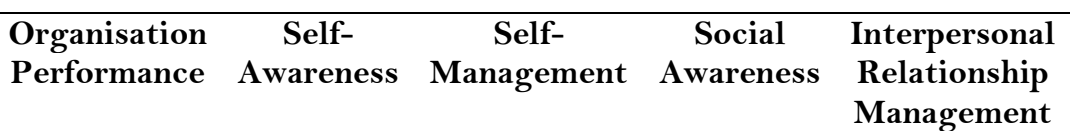

\begin{tabular}{|c|c|c|c|c|c|}
\hline \multirow{4}{*}{$\begin{array}{l}\text { Organisation } \\
\text { Performance }\end{array}$} & & & & & \\
\hline & Pearson & 1 & & & \\
\hline & Correlation & & & & \\
\hline & Sig. (2-tailed) & & & & \\
\hline \multirow{4}{*}{ Self-Awareness } & $\mathrm{N}$ & 153 & & & \\
\hline & Pearson & .101 & 1 & & \\
\hline & Correlation & & & & \\
\hline & Sig. (2-tailed) & .007 & & & \\
\hline & $\mathrm{N}$ & 153 & 153 & & \\
\hline Self-Management & Pearson & .414 & .147 & 1 & \\
\hline
\end{tabular}




\begin{tabular}{|c|c|c|c|c|c|c|}
\hline & Sig. (2-tailed) & .006 & .070 & & & \\
\hline & $\mathrm{N}^{\circ}$ & 153 & 153 & 153 & & \\
\hline \multirow[t]{4}{*}{ Social Awareness } & Pearson & .310 & .021 & .141 & 1 & \\
\hline & Correlation & & & & & \\
\hline & Sig. (2-tailed) & .017 & .792 & .082 & & \\
\hline & $\mathrm{N}$ & 153 & 153 & 153 & 153 & \\
\hline \multirow{4}{*}{$\begin{array}{l}\text { Interpersonal } \\
\text { Relationship } \\
\text { Management }\end{array}$} & Pearson & .528 & .095 & .097 & .052 & 1 \\
\hline & Correlation & & & & & \\
\hline & Sig. (2-tailed) & .015 & .245 & .234 & .524 & \\
\hline & $\mathrm{N}$ & 153 & 153 & 153 & 153 & 153 \\
\hline
\end{tabular}

Source: Survey Data (2018)

The results in Table 7 showed that the correlation coefficient between organisation performance and self-awareness was 0.101 indicating a weak positive correlation. The results also showed that the correlation coefficient between organisation performance and self-management was 0.414 suggesting that there was a moderate positive correlation between organisation performance and self-management. In addition, the results showed that the correlation between organisation performance and social awareness was 0.310 , an indication that social awareness was moderately correlated with organisation performance. Finally, the correlation coefficient between organisation performance and interpersonal relationship management was 0.528 indicating that there was strong positive correlation between interpersonal relationship management and organisation performance. All the coefficients had a P-value of less than 0.05 indicating that they were significant. The conclusion that emotional intelligence has a significant influence on organisation performance was consistent with the conclusions reached by Mwathi (2013) who concluded that emotional intelligence influences employee performance which in turn influences organisation performance. On the other hand, the results failed to agree with the conclusion of Omondi (2016) that there is a strong significant relationship between emotional intelligence and performance as measured through job satisfaction. However, Omondi's study was a case study conducted in the public sector at Kenya Post Office Savings Bank while the current study was conducted in the insurance industry which is predominantly privately owned.

\section{Conclusion}

The objective of this study was to assess the influence of emotional intelligence on the performance of Kenyan based insurance firms. It was established that emotional intelligence was emphasised to a moderate extent in the insurance industry in Kenya. In particular, interpersonal relations was the most emphasised aspect of emotional intelligence followed by self-management and social awareness while self-awareness was least emphasised. Correlation analysis revealed that there exist a weak positive correlation between self-awareness and organisation performance. Selfmanagement, social awareness, and organisation performance were moderately correlated while interpersonal relationship management was strongly correlated with organisation performance. All correlations were positive and significant. Regression results showed that self-awareness, self-management, social awareness, and interpersonal relationship management have a significant impact on organizational performance among insurance companies in Kenya. It was thus concluded that emotional intelligence has a significant influence on organizational performance among insurance companies in Kenya.

\section{Recommendation}

It was established that emotional intelligence was emphasised to a moderate extent among insurance companies in Kenya. It was also noted that there exist a positive relationship between emotional intelligence and organizational performance. The study thus recommends that the management staff of insurance companies should put more emphasis on emotional intelligence. Insurance companies should ensure that there are programs that are specially designed to offer training and enhancement of self-awareness to help the management staff and employees to be emotionally stable and make optimal decisions.

The study also concluded that self-awareness, self-management, social awareness, and interpersonal relationship management have a significant impact on organizational performance among insurance companies in Kenya. The study also recommends that employees should be trained on self-management, social awareness, and interpersonal relations so as to increase the performance level of the firm. Moreover, regulators in the market, specifically, the Insurance Regulatory Authority should emphasise on the adoption of emotional intelligence among insurance companies to improve on their performance. 
However, the results in this study were based on data collected from insurance companies in Kenya, meaning that the findings were only applicable to insurance companies in Kenya. Owing to generalizability constraint, this study suggests that more research should be done in other organisations rather than those in the insurance industry in Kenya. The study further suggests that other studies be conducted among other insurance companies within the East African Community to determine if there are cross-border factors that influence the relationship between emotional intelligence and performance of insurance companies.

Further, the study findings were based on data for a ten year period starting from 2008 to 2017. The period covered by the study was affected by post-election violence. The study found that the results could therefore not be extrapolated for longer periods due to the ever changing business environment in which the insurance companies operate. This study thus suggests that other studies be conducted covering longer periods beyond 10 years to determine if similar results would be posted.

\section{References}

Acha, V. (2013). The relationship between emotional intelligence of a leader and employee motivation to job performance (Unpublished doctoral dissertation), Capella University, USA.

Alipour, M. (2012). The effect of intellectual capital on firm performance: an investigation of Iran insurance companies. Measuring Business Excellence, 16(1), 53-66.

Almajali, A. Y., Alamro, S. A., \& Al-Soub, Y. Z. (2012). Factors affecting the financial performance of Jordanian insurance companies listed at Amman Stock Exchange. Journal of Management Research, 4(2), 266- 275.

Bell, J. (2010): Doing your Research Project. A guide for first time researchers in Education, Health and Social Science: 5th Edition, New York, McGraw- Hill.

Birgit, H. (2010). The relationship between emotional intelligence and leadership among middle managers in Namibia (Doctoral dissertation).

Brackett, M. A., Rivers, S. E., \& Salovey, P. (2011). Emotional intelligence: Implications for personal, social, academic, and workplace success. Social and Personality Psychology Compass, 5(1), 88-103.

Bryman, A., \& Bell, E. (2015). Business research methods. Oxford, United Kingdom: Oxford University Press.

Corvellec, H. (Ed.). (2018). Stories of achievements: Narrative features of organizational performance. Routledge.

Dancey, C. P., \& Reidy, J. (2004). Statistics without Maths for Psychology (Harlow.

Hang, D, T. (2014). Determinants of innovation commercialization management and anticipated returns: An exploratory typology of SMEs. International Journal of Innovation and Technology Management, 11(06), 1450042 .

Harter, S. (1978). Effectance motivation reconsidered. Toward a developmental model. Human development, 21(1), 3464.

Harter, S. (1981). A new self-report scale of intrinsic versus extrinsic orientation in the classroom: Motivational and informational components. Developmental psychology, $17(3), 300$.

Harter, S. (1981). A new self-report scale of intrinsic versus extrinsic orientation in the classroom: Motivational and informational components. Developmental psychology, 17(3), 300-319.

IRA (2010). Insurance Regulatory Authority annual report. Nairobi, Kenya: Author.

Mohanty, K., \& Kar, S. (2012). Achieving innovation and success: organizational learning. SCMS Journal of Indian Management, 9(1), 36-51.

Mwangi, M., \& Murigu, J. W. (2015). The determinants of financial performance in general insurance companies in Kenya. European Scientific Journal, ESJ, $11(1)$.

Mwathi, K. B. (2010). Relationship between emotional intelligence and job performance among service providers in rehabilitation schools in Kenya (Unpublished doctoral dissertation), University of Nairobi, Kenya.

Ndura, K. M. (2010). Effects of mergers on financial performance of insurance companies in Kenya. Unpublished Dissertation, School of Business, University of Nairobi.

Ngugi, B. K. (2007). Relationship between corporate governance structures and performance of insurance companies in Kenya (Unpublished doctoral dissertation), University of Nairobi, Kenya.

Ntinyari, E. (2014). Competencies preferred by employers of interior design graduates in kenya (Doctoral dissertation, Master Thesis), University of Nairobi).

Nzomo, L. N. (2012). Relationship between Principals' Emotional Intelligence and Students' Learning Achievements in Public Secondary Schools in Nairobi County, Kenya (Unpublished doctoral dissertation), University of Nairobi, Kenya.

Omondi, G. A. (2016). Influence of manager's emotional intelligence on employee job satisfaction at the Kenya post office savings bank (Unpublished doctoral dissertation), University of Nairobi, Kenya.

Qiao, J. L., Zhang, X. T., \& Cheng, Q. Q. (2016). Based on the Competency Theory of the New Generation of Migrant Workers Professional Ability Study. In Proceedings of the 6th international asia conference on industrial engineering and management innovation (pp. 779-786). Atlantis Press, Paris.

Saunders, M. L., \& Lewis, P \& Thornhill, A. (2009). Research methods for business students, 4th Ed. Uttar Pradesh: Pearson Education Limited

Saunders, M. N. (2011). Research methods for business students, $5^{\text {th }}$ Ed. Uttar Pradesh: Pearson Education Limited

Smith, J. A. (Ed.). (2015). Qualitative psychology: A practical guide to research methods. California: Sage publications. 
Taylor, S. J., Bogdan, R., \& DeVault, M. (2015). Introduction to qualitative research methods: A guidebook and resource. New Jersey: John Wiley \& Sons.

Teece, D. J. (2010). Technological innovation and the theory of the firm: the role of enterprise-level knowledge, complementarities, and (dynamic) capabilities. In Handbook of the economics of innovation (Vol. 1, pp. 679-730). North-Holland.

Vito-Thomas, D., Allyn, P., Wagner, L. B., Hodges, T., \& Streitmatter, S. S. (2018). The Evidence-Based Practice Fulcrum: Balancing leadership and emotional intelligence in nursing and interprofessional education.

Wambua, S. M. (2016). Effect of Human Resource Management Practices on Employee Performance in Commercial Banks in Nairobi County, Kenya. Strategic journal of business $\mathcal{E}^{2}$ change management, 3(2), 675-694.

Watson, D. (2000). Basic problems in positive mood regulation. Psychological Inquiry, 11(3), 205-209.

This is an Open Access article distributed under the terms of the Creative Commons Attribution Licence

(c) (†) 